International Journal of Social Science And Human Research

ISSN(print): 2644-0679, ISSN(online): 2644-0695

Volume 04 Issue 08 August 2021

DOI: 10.47191/ijsshr/v4-i8-41, Impact factor-5.586

Page No: 2244-2256

\title{
Inventory of Counterfeit Drugs, History of Antibiotics and Presentation of the Ministry in Charge with Four of the Largest Public Health Centers in Niger Using Them in 2016-2017
}

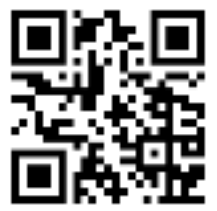

\author{
Salifou Karimoune FADJIMATA ${ }^{1}$, Amadou Tidjani ILAGOUMA ${ }^{2}$, BOUKARI Issiaka ${ }^{3}$ \\ 1,2 Materials, water and environment laboratory (MWEL), Faculty of Sciences and Technik, Department of Chemistry, Abdou \\ Moumouni University. BP 10662, Niamey (Niger) \\ ${ }^{3}$ École Normale Supérieure (ENS), Department of Chemistry, Abdou Moumouni University. BP 10963, Niamey (Niger)
}

\begin{abstract}
Context: Counterfeit medicine is a substance capable of curing a living, which is made fraudulently without responding to WHO standards. Today, the population Street increasingly to illicit markets to buy drugs at lower cost to the sellers. So, the sale of counterfeit medicines has first become the problem that tempts the media. Those drug supply have become not only a threat to the health of the population but also to the economy and security of many countries including in Niger. The street drug trade is a very growing activity in Niger. Antibiotic is a drug which treats infectious bacterial diseases. Associated with vaccination, it eliminates or greatly reduces the main epidemic diseases.

Evidence: Surveys on the use of drugs and in particular antibiotics have been carried out. The people targeted are those of the Ministry of Public Health, health workers stationed in hospitals and referral health centers; pharmacists and drugstore vendors, street vendors.

Results: The presentation of Ministry of Public Health in charge of health belonging to 4 greatest health centers were recorded as being used by the Nigerien population to have the most commonly antibiotics used by them. The Beta-lactam family (Amoxicillin, Ampicillin and Cloxacillin) (60/100); the Fluoro-quinolones family (ciprofloxacin) (20/100); the imidazole family (Metronidazol) (20/100) were the most used species.

Conclusion: The review on counterfeit drugs, the history of antibiotics and the presentation of the main health centers involved in Niger provided substantial details on the use of drugs to treat infectious diseases. These complete basic data could certainly encourage some researchers to undertake research on other molecules which could lead to the quality control of these drugs for the treatment of the diseases which concern them and to have notions on the functioning of the services concerned by approaching these latter.
\end{abstract}

KEYWORDS: Counterfeit drugs, infectious diseases, heath centers, Niger.

\section{CONTEXT}

Nowadays, the sale of counterfeit medicines has first become the problem that tempts the media, then an overview of the policy against fake medicines and street drugs; we can retain among the following studies: In 1999, WHO published a study on pharmaceutical counterfeiting, which for the first time used the method of detecting by investigating the authenticity of drugs. This survey was carried out in Vietnam and Myanmar at the level of public and private pharmacies as well as at the street markets. All of the products collected were subjected to laboratory tests to determine the identity of the active ingredient and the quantity present in the preparation, then were the subject of research to authenticate their origin (manufacturer and country of production). If a product had a quality problem but came from an authentic source, further investigation was recommended to establish whether or not the non-compliance was willful. Although it is specified in the report that the investigation requires contacts with the pharmaceutical regulatory authorities of the country of production and the manufacturers, the letters of inquiry and the samples were only sent to the authorities. They were asked to indicate for each drug whether it was well manufactured in the country, if the manufacturer was well licensed, if the product was well registered / authorized for sale and, finally, if the product was indeed authentic. To respond to this last request, the pharmaceutical regulatory authorities were supposed to contact the manufacturer concerned[1]-[3]. WHO estimates that:

$\checkmark \quad 65 \%$ of fake medicines come from developing countries,

$\checkmark \quad 25 \%$ come from industrialized countries and 


\section{Inventory of Counterfeit Drugs, History of Antibiotics and Presentation of the Ministry in Charge with Four of the Largest Public Health Centers in Niger Using Them in 2016-2017}

\section{$\checkmark \quad 10 \%$ of non-specific sources[4].}

According to a survey carried out by Cracking Counterfeit Europe in 14 European countries on behalf of Pfizer, the market for counterfeit medicines is exploding. According to this study, in France, $14 \%$ of people recognize buying outside authorized circuits prescription drugs only. The number of counterfeit drugs seized at Europe's borders has increased six-fold in two years, from more than half a million in 2005 to more than 4 million in 2007. The results of this survey show that $32 \%$ of French respondents buy online to save time, $32 \%$ to save money and $27 \%$ to obtain a prescription drug without a prescription [5], [6].

However, almost $35 \%$ of French respondents do not know the risks associated with the consumption of counterfeit medicines. They are unaware that the active ingredient may be too small or too high, or even absent. Finally, they are not aware of the fact that these fake drugs can cause therapeutic failures and, in the worst case, lead to death[7], [8].

The investigation of the authenticity of medicines recommended by the WHO has been carried out only very rarely and always in an incomplete manner. The difficulty and the length of this kind of investigation are surely at the origin. To our knowledge, only 3 studies have attempted this; ReMed is a French association which has carried out several studies on the quality of medicines in developing countries. One of them took place in Chad in 1995 and aimed to assess the quality of generic anti-tuberculosis drugs there after their transport and storage under local conditions 36. The results showed that these factors were not generally responsible for the non-conformities observed for most of the samples analyzed (33/48). Although the search for other causes of nonconformities (counterfeiting or workmanship) was not initially planned in the procedure, it was therefore interesting to try to identify them[9]-[11].

The results of the analyzes of the 33 non-compliant samples were therefore sent to the directors of the 8 European pharmaceutical industries concerned, in the hope of obtaining relevant explanations on the origin of the defects. Six industries responded: among them, 4 contradicted the results, 1 evaded the question and the last hypothesized that its product was counterfeit (the lot number of the offending drug did not match their registrations). The report does not specify the name and type of non-compliance of the potentially counterfeit product, but it should be noted that none of the non-conformities noted in the study was particularly likely to raise the suspicion of fraud ( no total substitution of the active principle by another active product or by an inert product and no under-dosage below the bar of $50 \%$ of the content indicated by the manufacturer).

This is not a study on counterfeiting, but the investigation carried out with the manufacturers turned out to be the only way to highlight the intentional nature or not of the nonconformities observed, and thus to take the measuring the quality problems of medicines in Chad[1[12]]-[3]. The first pitfall of this study is to have carried out an investigation of selective authenticity.

The second survey, which took place in 2002-2003, is an improved version of the first. The list of targeted drugs has been expanded, including artemisinin derivatives (artesunate and artemether) and mefloquine. The detection method, still based on laboratory tests, this time combined the colorimetric test with high performance liquid chromatography (HPLC), allowing a qualitative then quantitative evaluation of the active ingredient. However, for unknown reasons, chromatography was only carried out for part of the samples showing a positive reaction to the colorimetric test (only 56 out of 89). Like the previous study, all of the products lacking an active ingredient were deemed to be counterfeit on this basis alone. However, this time, some products containing too little active ingredient (here, on average $7 \%$ of the content indicated) were also found to be counterfeit. In addition, comparative organoleptic tests were carried out to verify the effectiveness of the predictive factors highlighted in the previous study. The authors found that the sensitivity, specificity and positive and negative predictive values of these factors decreased due to the sophistication of the counterfeits, which are sometimes indistinguishable from the originals.

The criticisms addressed to the first study can be repeated here, even if a small improvement has been made by extending the scope of detection to drugs containing the expected active ingredient (s). If other samples were non-compliant, it would be interesting to know the threshold beyond which a drug is supposed to be "probably" authentic and on what grounds[10], [12].

L. Basco, in his article on the quality of antimalarials in Cameroon, made it clear that he did not want to use the WHO definition of counterfeit drugs; it seems too restrictive. He therefore specified that he would not take any steps to verify the origin of the products collected. He preferred to propose a personal definition, more oriented towards laboratory practices.

Thus, were declared counterfeit, medicinal products for which the results in a colorimetric test were not positive for medicinal products for which the results of thin layer chromatography revealed a spot located at a distance different from that of the reference product or whose intensity was less than $80 \%$ of that of the reference product. The author also specified that he would not use the term non-compliant either since, according to him, it only applies to the quality of authentic medicines produced by authorized manufacturers.

According to WHO criteria, the definition used by Basco can only detect drugs that do not meet quality standards. It is therefore inappropriate to use the words "Counterfeit" or "Authentic" since the origin and cause of the non-conformities are not identified[13], [13].

As Shakoor et al. during one of their studies on the quality of medicines, it is very difficult to attribute the non-conformity of samples to a particular reason (malice or simple error) without having details of the manufacturing procedure or even documents on the origin of the constituents, in particular if there is no obvious error in the labeling of the medicinal products. Without this 


\section{Inventory of Counterfeit Drugs, History of Antibiotics and Presentation of the Ministry in Charge with Four of the Largest Public Health Centers in Niger Using Them in 2016-2017}

information, which only the pharmaceutical industries hold, we can only make hypotheses but no certainty. This is one of the reasons why the WHO advises to contact the manufacturer mentioned on the label but also the pharmaceutical regulatory authorities of the countries of marketing and manufacture. In fact, the manufacturer is the only one who can formally attest to the authenticity of a drug that he is supposed to have produced, and the authorities can give essential information on the legality of the product and the manufacturer (authorization, license, etc.). The answers provided by these investigations are necessary to affirm that a product is counterfeit, even if qualitative analyzes already allow us to suspect it (no active ingredient, bad active ingredient, etc.). Human error is always possible, including in cases of serious non-compliance, in particular in countries where Good Manufacturing Practices are not well followed. As proof, the large number of withdrawals of batches of authentic medicines carried out each year by the authorities, even in developed countries. Often the problems are minimal and it is for security that withdrawals take place. But sometimes it is much more damaging errors that are involved. They can affect both the labeling and the quality of the medicine[10]. Abdoulaye and coll. evaluated in 2003 towards a campaign to fight the illicit market in medicines, essentially based on awareness spots which were broadcast on the radio and especially on television in the city of Cotonou (Benin). It was a quantitative, transversal, descriptive and analytical study which aimed to determine the proportion of people who received the awareness messages, to know what the sensitized respondents retained as key messages and to identify the change in their behavior after consumed street drugs before the awareness campaign. They investigated 300 heads of household (father or mother) distributed in the sectors of the city in 30 clusters of 10 survey units. The results of this study show:

$\checkmark$ The street drugs consumption rate in 2003 was estimated at $36 \%$;

$\checkmark \quad 85.3 \%$ of the respondents declared having received messages concerning the drugs through the communication channels that are television $(89.5 \%)$, radio $(78.1 \%)$

$\checkmark$ The themes retained in the content of the messages are as follows: $89.4 \%$ ban on the sale of drugs in the street or in the market; street drugs are dangerous for $92.5 \%$; there are cheaper and effective drugs for $41.2 \%$;

$\checkmark$ Finally, during the last three months of their study, $51.1 \%$ of households having used street drugs in the past have given up on these practices.

The authors estimated that even if the level of education improved, the marital status, and the possession of a television set favorably influenced this attitude, the awareness and the improvement of the availability of the Essential Generic Medicines taken in isolation or in association have played a big role in this behavior change[14], [15]. He obtained a prevalence of $40 \%$ of buyers of street drugs or $68.98 \%$ of the population. The main reason for purchasing street drugs was low prices[16], [17].

Tiendrebeogo A.F. estimated in 1997 the street drugs consumption rate in Ouagadougou is more than $20 \%$ and that street drugs occupied more than $10 \%$ of the city's pharmaceutical market. According to him, the vast majority of poor populations and part of those of illiterate rich or middle-income populations are heavy consumers and that there are even wealthy people and intellectuals among the consumers[18].

Mélanie Mazière, Managing Director of NAFDAC (National Agency for Food and Drug Administration and Control) in Nigeria has enabled her country to reduce the percentage of counterfeit medicines from 70 or $80 \%$ to less than $10 \%$ in 6 years (2001-2007). To achieve this, Mélanie used the following strategies:

$\checkmark$ first rejected all bribes;

$\checkmark \quad$ restructured the agency;

$\checkmark$ implementation of border surveillance;

$\checkmark$ launched inspections in India, where Nigerian counterfeiters obtained their supplies;

$\checkmark$ Organized general public information campaigns (even using literary competitions in high schools);

$\checkmark$ Ordered police raids where the products in question were stored;

$\checkmark$ Instructed surprise checks in the production plants and proceeded to the public incineration of tons of seized drugs;

$\checkmark$ She even persuaded banks not to authorize loans to people involved in the pharmaceutical trade without NAFDAC certification, and threatened foreign airlines with a flight ban if they were used to bring in drugs parallels on Nigerian territory[19], [20].

Odile and coll. Have carried out a well-informed descriptive and analytical cross-sectional study which took place from December 5, 2007 to January 10, 2008 in the town of Adjamé in the Republic of Côte d'Ivoire gave the following results: the investigation of 300 people aged 18 and over, showed a $72 \%$ prevalence of street drug purchases with a high proportion of men representing 67.59 $\%[16],[17]$.

Dr. Diallo Moustapha, evaluated the share of the illicit market in imports into Niger represents on average $75 \%$ of the global market for the period from 1999 to 2003[21].

So; the fraudulent sale of drugs in the informal sector, called street drugs, has become a public health problem worldwide, and more particularly in sub-Saharan Africa, including Niger.

The informal drug network experienced a boom in Niger with the advent of a multiparty system from 1991 and the lifting of the ONPPC monopoly in 1997. Despite the existence of legislation which specifies the pharmacist's monopoly in the field of drugs, the 


\section{Inventory of Counterfeit Drugs, History of Antibiotics and Presentation of the Ministry in Charge with Four of the Largest Public Health Centers in Niger Using Them in 2016-2017}

illicit drug distribution circuit has developed in a diffuse way in all the regions of Niger, by the proliferation of a multitude of street vendors, most often from unemployed youth. The omnipresence of this informal market is a real health problem in Niger[22].

Thus, street drugs have several origins. They mainly come from the informal sector and are smuggled into Nigerian territory, in violation of the regulations in force regarding the import of medicines. The import of medicines into Niger is subject to prior authorization from the Ministry of Public Health and all structures operating in this context must meet certain very technical criteria which demonstrate their competence in managing pharmaceutical products which are not ordinary goods. Pharmaceutical products are very specific and therefore the management requires a high degree of technicality.

Consumption of counterfeit in general and antibiotics in particular results in neurological, hematological, hepatic, pulmonary, renal problems in the elderly (Nephrology Department of Lamordé Hospital), allergic conditions linked to their toxicity and resistance.

Today, those drug supply have become not only a threat to the health of the population but also to the economy and security of our country.

The street drug trade is a very growing activity in Niger. Indeed, the consequences of this illegal sale can be grouped into four (4) sectors:

- In terms of public health: we have an emergence of resistance to antibiotic treatments, the ineffectiveness of the products against certain diseases, acute and chronic intoxication, liver, kidney and heart damage; then an increase in drug addiction which has physical and psychological consequences. The investigation reveals the harmful effects which one notes in the taking of the drugs without prescription and without follow-up of the doctor or pharmacist[23], [24].

- From a social point of view: we can cite, among other things, the resurgence of delinquency, the increase in organized crime and criminality which are linked to the consumption of amphetamines and other drugs acquired on the parallel market of street drugs[21], [25], [26].

- In terms of pharmaceutical regulation: the appearance and development of the illicit market undermine the integrity of the pharmacist as defined by Order No. 97-002 of January 10, 1997 on ratified pharmaceutical legislation by law $\mathrm{N}^{\circ} 97-05$ of June 02 , 1997 and its implementing decree, decree $N^{\circ}$ 97-301 / PRN / MSP of 06 August 1997[26].

- At the macroeconomic level: several central purchasing offices and pharmacies have seen their turnover fall. Pharmacies have closed for lack of profitability. This is the case in particular of the popular Habou-Béné pharmacy which was profitable at the opening, and which is now closed, as it can no longer bear the unfair competition from illicit wholesalers installed in the large market of Niamey and which surround this public dispensary. Parallel trafficking endangers wholesalers repairing drugs; private pharmacies, private warehouses and health facilities cause a shortfall for the state in taxes and taxation[21].

Thus, while countries are struggling to fight against this scourge in the approved structures, the illicit sale of medicines in the informal sector would probably be a privileged channel for its sale and is in full expansion through the cities and villages of the country; street vendors roam the streets, around markets, in families and even in services and places of worship.

Significant quantities of medicines are exhibited by wholesalers located in the markets of Niamey.

Also, health workers are increasingly giving themselves to this parallel illegal sale of drugs inside health facilities, illustrating the magnitude of the problem. These drugs sold in the parallel market have several sources:

$\checkmark$ free medical samples from pharmaceutical laboratories;

$\checkmark$ orders from non-approved laboratories;

$\checkmark$ donations.

Studies carried out in the West African sub-region show that the consumption of street medicines can be explained by the low cost of Street Medicines which defies all competition: indeed, because the sellers in the informal sector escape in taxation, invest less for their installation, acquire their medicines at lower costs taking into account their origin (theft, embezzlement, counterfeiting, expiration); they are able to sell them at prices that defy competition to approved structures[21], [27].

The Power of Orality in Niger: Tacit Trust Between People Makes Advice

lavished by some in sharing experiences are very quickly accepted;

The influence of those around them: buyers of street drugs are often influenced by those around them (the case of women and their spouses).

The ignorance of the population: illiteracy and poverty reduce access to information on the dangers linked to the consumption of street drugs conveyed by the usual channels (written newspapers, televisions, radios, internet ...).

The irrational prescriptions of health professionals who make care relatively high in health centers: whatever is induced or linked to the incompetence of the actors, this sad reality contributes to make expensive the care of patients in health facilities and therefore urge the latter to seek other alternatives, including self-medication with very often street drugs[28].

Indeed, the reception of customers in public health facilities is considered unsatisfactory by the latter who see their dignity flouted while access to private structures, where reception is better, is limited geographically and or financially for the majority of Nigerians. Added to this is the high opportunity cost of long patient waiting times in health centers[29]. 


\section{Inventory of Counterfeit Drugs, History of Antibiotics and Presentation of the Ministry in Charge with Four of the Largest Public Health Centers in Niger Using Them in 2016-2017}

However, a struggle is waged by the various structures and organizations but not evaluated. Indeed, since the drugs are victims of counterfeiting and it is imperative for the government and manufacturers to cooperate to detect and prevent the increasing numbers of exports, smuggled, falsely labeled, falsified, counterfeit pharmaceutical preparations not meeting WHO standards.

\section{DEFINITION, ROLE AND HISTORICAL OF ANTIBIOTICS}

Antibiotics in particular have provided effective treatments for most major bacterial infectious diseases. Combined with vaccination, they have contributed to greatly eliminating or reducing major epidemic diseases, at least in developed countries: tuberculosis, plague, leprosy, typhus, typhoid fever... They are also used in cases of cholera in addition rehydration of patients [30].

The principle of action of antibiotics consists in selectively blocking a stage in a mechanism essential for the survival or multiplication of microorganisms. The mechanism targeted by the antibiotic is most often specific to bacteria and has no equivalent in eukaryotes and in particular in humans[31]. Ideally, the antibiotic kills or blocks the multiplication of bacteria but $\mathrm{n}$ has no impact on the cells of the treated patient[32].

Since antiquity, growing molds of bread and soybeans have been the subject of empirical use to cure infections; however, after the adoption of the germ theory, and then under the impetus of the theory of evolution, the story of what was called antibiotics really began. The diffusion of antibiotics from the end of the years 1940 had a considerable impact on the health of populations, medical practice and scientific research. Their use in veterinary medicine as well as in agriculture led to equally significant changes[31], [33].

Some observations, fortuitous or provoked, incited various scientists to identify harmless bacteria which could oppose the development of pathogenic bacteria.

Already in 1877, Pasteur and Jules Joubert observed that injecting rats with a solution containing anthrax and various soil bacteria did not lead the rats to develop anthrax. Through this work, Pasteur provided the first clear and unequivocal description of microbial antagonism that other researchers had been able to indicate before him. In addition, he glimpsed the therapeutic possibilities of this phenomenon Auzias-Turenne, who died in 1870, had already advocated the use of microbial antagonisms for therapeutic purposes. His ideas on this subject are found in his posthumous work La Syphilisation[31], [33]-[36].

In 1885 Arnaldo Cantani treated cases of pulmonary tuberculosis with sprays of Bacterium termo in the lungs[31], [33]-[36].

In 1887, Rudolf Emmerich showed that animals to which the streptococcus had previously been injected did not develop cholera[31], [33]-[36].

In 1888 Victor Babeş shows that certain saprophytic bacteria inhibit the development of Mycobacterium tuberculosis and an antibacterial substance was extracted from Bacillus pyocyaneus by E. Von Freudenreich [31], [33]-[36].

In 1889 Bouchard showed that the injection of Pseudomonas aeruginosa prevented the development of anthrax in rats. Rudolf Emmerich and Oscar Löw are carrying out clinical trials on an antibiotic substance, the pyocyanase produced by Bacillus pyocyaneus a bacterium today called Pseudomonas aeruginosa. Unstable and toxic, the drug was abandoned (but had some applications in the form of an ointment for dermatoses) [31], [33]-[36].

Several hundred examples of microbial antagonism were thus brought to light without having any practical effect. This is partly due to the attention then given to another path of research, chemotherapy, following the discovery of arsphenamine (Salvarsan). In addition, the therapeutic use of the recently discovered bacteriophages also seemed promising at the time[31], [33]-[36]. At the same time (in 1889) Paul Vuillemin proposed the term antibiosis in opposition to the phenomenon of symbiosis, to describe the phenomenon of antagonism between two microbial species.

In 1903 Paul Ehrlich (1854-1915) discovers of Trypan Röd (the first anti-parasitic antibiotic) by Paul Ehrlich (1854-1915) [31], [33]-[36].

In 1909 Paul Ehrlich discovers of Salvarsan (606), a powerful anti-syphilitic[31], [33]-[36].

In 1921 Ernest Fourneau (1872-1949) synthesizes of Stovarsol (low toxicity antimicrobial derived from arsenic) [31], [33]-[36]. In 1928 Alexander Fleming (figure 1) discovers the antibiotic action of Penicillium and name the first antibiotic as penicillin (figure 2) [30], [33].

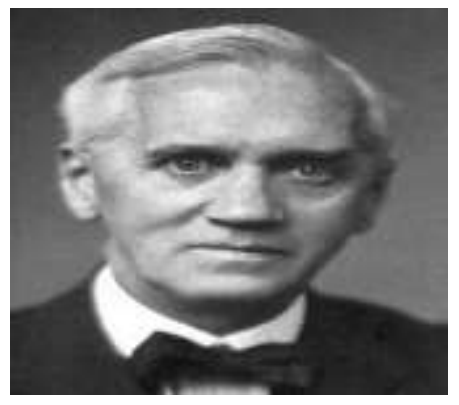

Figure 1: Alexander Fleming, in 1928 [30]

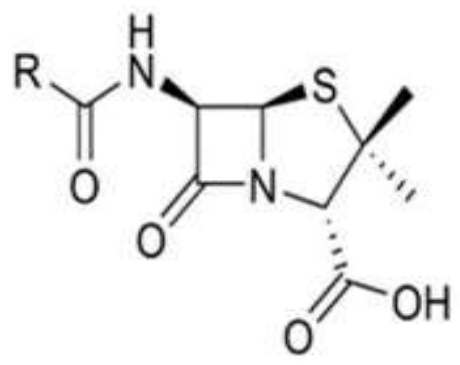

Figure 2: Structure of penicillin [30] 


\section{Inventory of Counterfeit Drugs, History of Antibiotics and Presentation of the Ministry in Charge with Four of the Largest Public Health Centers in Niger Using Them in 2016-2017}

If at the end of the 19 th century Ernest Duchesne discovered the healing properties of Penicillium glaucum, the discovery of penicillin is to the credit of Sir Alexander Fleming who discovered in 1928 that some of his bacterial cultures in forgotten boxes had been contaminated by the experiences of its bench-top neighbor studying the fungus Penicillium notatum and that this inhibited their reproduction. But the importance of this discovery, its implications and its medical uses were understood and developed only after its rediscovery, between the two great wars in particular following the work of Howard Walter Florey, Ernst Chain, and Norman Heatley in 1939[30], [33].

In 1932 Gehrad Dogmak (1895-1964) synthesizes the general anti-microbial Prontosil[31], [33]-[36].

In 1935 Thérèse and Jacques Tréfouel (1897-1977), Federico Nitti, Daniel Bovet and Constantin Levaditi (1874-1953) demonstrate the antibacterial activity of sulfonamides derived from Prontosil. This first synthetic antibiotic opened a new path in the fight against many diseases that were considered incurable before[31], [33]-[36].

In 1939 Ernst Chain and Howard Florey obtain pure penicillin. At the same time René Dubos (1901-1982) and Rollin Hotchkiss isolated tyrothricin (a mixture of tyrocidin and gramicidin) at the Rockefeller Institute in New York[31], [33]-[36].

In 1940, Selman A. Waksman (1888-1973) made the isolation of actinomycin[31], [33]-[36].

In 1942, the industrial preparation of penicillin begins in Eli Lilly laboratory[31], [33]-[36].

In 1943 Selman Waksman made the isolation of streptomycin which is the first effective antibiotic against tuberculosis and he became winner of the Nobel Prize in physiology or medicine in 1952[31], [33]-[36].

In 1944, Selman Waksman discovered an antibiotic active against Gram-negative bacteria (streptomycin) and above all, against Koch's bacillus for anti-tuberculosis treatment[31], [33]-[36].

In 1945, Alexander Fleming, Howard Florey and Ernst Chain jointly made the isolation and therapeutic use of penicillin, and they receive the Nobel Prize in Physiology or Medicine for the discovery[31], [33]-[36].

In 1945, the marketing of antibiotics and the beginning of industrial preparation of them[31], [33]-[36].

In 1947, René Dubos and Selman A. Waksman proposed the following definitions in order to reduce ambiguities on the meaning of the term antibiotic[31].

In 1949, an antibiotic called tetracyclines which block protein synthesis in bacteria has been discovered[31], [33]-[36].

In 1950, some pathogenic bacteria that have become resistant to the usual antibiotics like penicillin, streptomycin, chloramphenicol was demonstrate in Japan[31], [33]-[36].

In 1952, erythromycin, the first known macrolide, newly isolated by J. M. McGuire, of the company Eli Lilly, was marketed under the Ilosone brand[31], [33]-[36].

In 1956 is discovered vancomycin. Then follow and

In 1960, $\mathrm{T}$. Watanabe demonstrates the genetic origin of antibiotic resistance: the responsible gene is carried by a bacterial plasmid (DNA ring independent of the chromosome) [31], [33]-[36].

In 1962 the development of quinolones was done[31], [33]-[36].

In 1965, it was development of semi-synthetic antibiotics[31], [33]-[36].

After 1970, research on antibiotics slowed down sharply, the therapeutic arsenal of the time then making it possible to effectively treat most bacterial infections[31], [33]-[36].

In 1980, discovery of new bacterial genetic elements, integrons, promote resistance to antibiotics, the derivatives of quinolones named fluoroquinolones were discovered[31], [33]-[36].

In 1990, it was beginning of the expansion of the epidemic of multidrug-resistant tuberculosis (street drugs) bacilli[31], [33]-[36]. In 2000, it was the first introduction in twenty years of a new class of antibiotics with the total synthesis of the first new generation antibiotic, linezolid (approved by the FDA on April 18, 2000) is put on the American market, it corresponds to a new class of compounds, oxazolidinones[31], [33]-[36].

In 2017, it was the introduction in France of the antibiotic Zavicefta® (produced by AstraZeneca) in the arsenal for the fight against multidrug-resistant bacteria.

The antibiotic takes its name from the Greek anti "against", and bios "life"; is a natural or synthetic molecule that destroys or blocks the growth of bacteria[30], [34]-[36].

Many antibiotics are natural molecules made by microorganisms: fungi or other bacteria.

In a simplified way, an antibiotic is, in the medical field, "an organic chemical substance of natural or synthetic origin inhibiting or killing pathogenic bacteria at low concentration and having a selective toxicity".

The different classes of antibiotics

Antibiotics are classified into ten (10) families[31], [37], [38] which are: betalactamines, glycopeptides and fosfomycin, aminoglycosides, macrolides and related, tetracyclines, phenicol, quinolones and fluoroquinolones, sulfonamide-trimethoprim, imidazole and anti-tuberculosis drugs. These families are divided into groups, which in turn are subdivided into subgroups. Their classification is presented in the table below[30]-[33]. (Table I) 
Inventory of Counterfeit Drugs, History of Antibiotics and Presentation of the Ministry in Charge with Four of the Largest Public Health Centers in Niger Using Them in 2016-2017

Table I: classification of antibiotics

\begin{tabular}{|c|c|c|}
\hline Antibiotic families & Antibiotic groups & Antibiotic subgroups \\
\hline \multirow{11}{*}{ Betalactamines } & \multirow[t]{4}{*}{ 1. Penams } & $\begin{array}{l}\text { Penicillin G : Procaine penicillin, Benzathine } \\
\text { penicillin, Phenoxypenicillin }\end{array}$ \\
\hline & & $\begin{array}{l}\text { Penicillin M : } \begin{array}{l}\text { Méthacillin, } \\
\text { Cloxacillin, }\end{array} \\
\text { Oxacillin, } \\
\text { Dicloxacillin, }\end{array}$ \\
\hline & & Aminopénicillines : \\
\hline & & $\begin{array}{l}\text { Ampicillin, } \quad \text { Bacampicillin, } \\
\text { Amoxicillin. }\end{array}$ \\
\hline & \multirow[t]{4}{*}{ 2. Cephems } & $\begin{array}{l}\text { Céphalosporines de 1ère génération : } \\
\text { Cefolatin, Cefator, Cefaloridine, Cefazoline, } \\
\text { Cefradine. }\end{array}$ \\
\hline & & $\begin{array}{l}\text { Céphalosporines de } \mathbf{2}^{\text {ème }} \text { génération : } \\
\text { Cefamandole, Cefuroxime, Cefoxitime. }\end{array}$ \\
\hline & & $\begin{array}{l}\text { Céphalosporines de } \mathbf{3}^{\text {ème }} \text { génération : } \\
\text { Cephamycins, Cefixime, Cefpodoxime, } \\
\text { Cefotaxime, Ceftazidime, Ceftriaxone. }\end{array}$ \\
\hline & & $\begin{array}{l}\text { Céphalosporines de 4ème génération : } \\
\text { Céfépime, Cefpisonne }\end{array}$ \\
\hline & 3. Carbapenems & Imipeneme, Mesopenem \\
\hline & 4. Oxapenems & $\begin{array}{l}\text { Amoxicillin + clavulanic acid, Ticarcillin + } \\
\text { clavulanic acid }\end{array}$ \\
\hline & 5. Monobactams & Aztreonames \\
\hline \multicolumn{3}{|c|}{$\begin{array}{l}\text { Glycopeptides and Vancomycin, Tei } \\
\text { Fosfomycin }\end{array}$} \\
\hline Aminoglycosides & $\begin{array}{l}\text { Streptomycin, Kanamycin, Neomycin, } \\
\text { Gentamicin, Netilmicin, Kanamycin, } \\
\text { Tobramycin, Amikacin }\end{array}$ & \\
\hline $\begin{array}{l}\text { Macrolides } \\
\text { related }\end{array}$ & 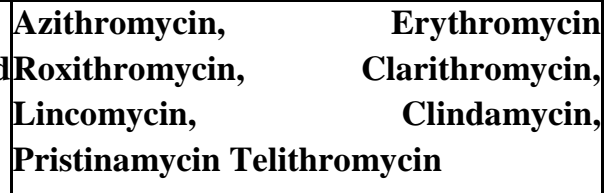 & \\
\hline Tetracyclines & $\begin{array}{l}\text { Oxytetracycline, Doxycycline } \\
\text { Minocycline }\end{array}$ & \\
\hline Phenicol & Chloramphenicol, Thiamphenicol & \\
\hline Quinolones anc & 1. Quinolones & Nalidixic acid, Pipemidic acid, Oxolinic acid. \\
\hline fluoroquinolones & 2. Fluoro-quinolones & Pefloxacin Ofloxacin \\
\hline \begin{tabular}{|l} 
Sulfonamide- \\
Trimethoprim
\end{tabular} & Sulfamethoxazole Trimethoprim & Co-trimoxazole \\
\hline Imidazole & Flagyl & Metronidazol \\
\hline $\begin{array}{l}\text { Anti-tuberculosis } \\
\text { drugs }\end{array}$ & $\begin{array}{l}\text { Ethambutol, Isoniazid, Pyrazinamide } \\
\text { Rifampicin, Streptomycin }\end{array}$ & \\
\hline
\end{tabular}

\section{EVIDENCE}

Our review is based on a few studies carried out on counterfeit medicines in Asia, Europe and Africa and more particularly in Niger and our analyzes included all the major health centers in Niger involved in counterfeit medicines through questionnaires which were issued to them. addressed. The people targeted are those of the Ministry of Public Health, health workers stationed in hospitals and referral health centers; pharmacists and drugstore vendors, street vendors. The effects and consequences of this illicit sale are grouped into four (4) sectors: in terms of public health; on the social plan; in terms of drug regulations and macroeconomics. Knowledge of these centers is required. For that; we inquired about the functioning of the services concerned by writing addressed 


\section{Inventory of Counterfeit Drugs, History of Antibiotics and Presentation of the Ministry in Charge with Four of the Largest Public Health Centers in Niger Using Them in 2016-2017}

to them. We identified them through their geographical location, we learned about their history and the missions carried out by each of these centers.

\section{RESULTS}

Four of greatest of health centers which are in Niamey and have been selected in the survey, namely:

$\checkmark$ Niamey National Hospital (HNN);

$\checkmark$ Amirou Garga National Hospital of Lamordé (HNL);

$\checkmark$ Issaka Gazobi Maternity (MIG);

$\checkmark$ Poudrière Regional Hospital Center (CHR-Poudrière).

The ministry in charge of using drugs for the health which covers all the health centers is in Niamey and it is called Ministry of Public Health and it would be important to talk about it.

\subsection{Presentation of the Ministry of Public Health}

\subsubsection{Geographic location}

Located in the center of all departments; the MSP is limited to the East by the Grand Chancellery and the National Malaria Control Program, to the North by the Embassy of Chad and the Association of Traditional Chefs, to the West by the Ministry of National Education and the Presidency, to the south by the green Villa.

\subsubsection{Historical}

The Ministry of Public Health is an institution of the State, created in 1957, responsible for ensuring the well-being of the population. From 1957, the date of the 1st government resulting from the overseas reform to the present day, this ministry in charge of the health of the Nigerien population has experienced several upheavals: From 1957 to 1960, it was known as the Ministry of Public Health. From June 1974 to March 1988; he took the name of Ministry of Public Health and Affairs Social following a reshuffle occurred on May 10, 1974 by decree $n^{\circ}$ 74-81 /PCMS /MSP/AS.

From June 2007 to the present day it took the name of Ministry of Public Health[39].

\subsubsection{Missions and Powers}

The mission of the MSP is to bring the people of Niger to the highest standard of health. It is the decree ${ }^{\circ}{ }^{\circ} 2013-427 \mathrm{PM}$ of October 09, 2013 specifying the attributions of the members of government.

In this capacity, the Minister of Public Health exercises the following powers:

$\checkmark$ the definition of the policy and the development of national strategies in Public Health;

$\checkmark$ the design and implementation of public health programs and projects;

$\checkmark$ the definition of standards and criteria in matters of public health and hygiene, as well as the control of the inspection of health services throughout the national territory;

$\checkmark$ the development, implementation and control of the application of the legislation and regulations governing the Public Health sector;

$\checkmark$ the mobilization of financial and material human resources for the implementation of public health sector policies and strategies;

$\checkmark$ coordinating, monitoring and developing the interventions of the various players in the MS sector;

$\checkmark$ supervision, control and monitoring of places and the exercise of worship;

$\checkmark$ guardianship and control of religious associations, leagues and religious councils as well as places of worship[39].

\subsection{Presentation of the different Health Centers of the Urban Community of Niamey}

The city of Niamey, brings together the main reference health centers in the country (figure 3, namely: National Hospital of Niamey created in 1922, National Hospital of Lamordé, old Center University Hospital having opened its doors in 1985, Regional Hospital Center of Poudrière, District Hospital of Gaweye now becomes RHC of Gaweye and the Maternity Issaka Gazobi which constitutes the only National Center of gynecological, obstetrical and neonatal references in the country's health system[40]. 

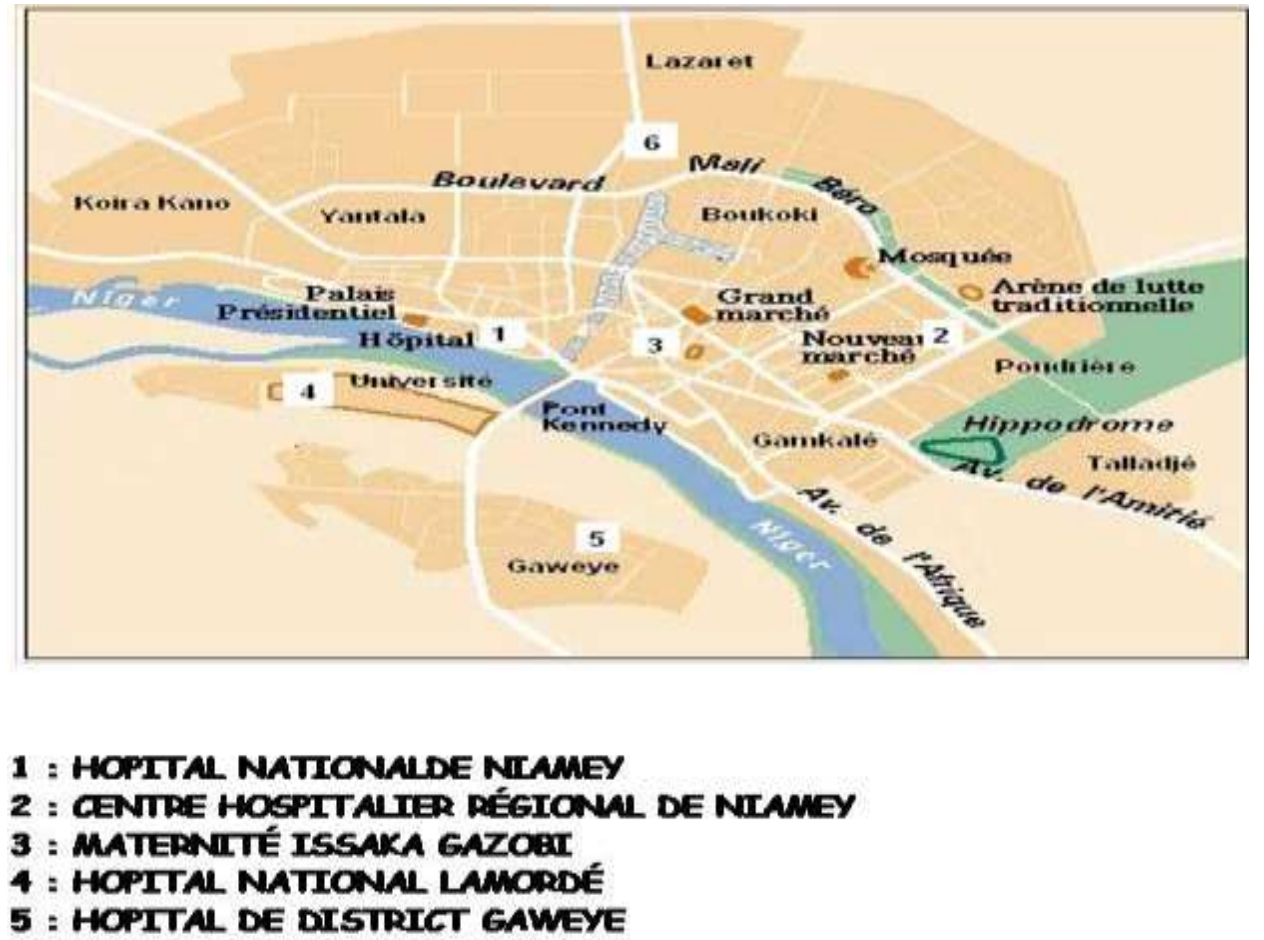

Figure 3: Geographic location of Niamey greatest Hospitals[41]

Four large public health centers in Niamey were targeted: National Hospital of Niamey, regional hospital of Niamey called Hospital Regional Center of Poudrière, Maternity Issaka Gazobi and National Hospital of Lamordé called Amirou Garga Hospital of Lamordé (HNL). The district hospital of Gaweye located on the right bank was not targeted because there is already a referral hospital on the right bank which is that of Lamordé where people go there in case of emergency; and as the left bank is more populated, some consult their except in case of necessity or if they are referred to the National Hospital of Niamey.

\subsubsection{Presentation of the Niamey National Hospital}

\subsubsection{Geographic location}

Niamey National Hospital covers an area of 5.41 hectares. It is limited:

$\checkmark \quad$ To the East by Avenue François Mitterrand

$\checkmark$ To the West by the administrative district, the Institute of Public Health (ISP) and part of the National School of Public Health (ENSP)

$\checkmark \quad$ In the North by the second part of the National School of Public Health (ENSP)

$\checkmark \quad$ In the South by the Kombo district[41].

\subsubsection{Historical}

It was created in 1922 to serve as a hospital for auxiliaries to the Colonial Administration (J. Brevier).

In 1962, it was erected as a National Reference Hospital.

In 1992, it becomes Public Establishment with character Administrative with civil personality and financial autonomy[41].

\subsubsection{Missions}

The different missions of the NHN are to:

$\checkmark \quad$ serve as a reference center for other health facilities;

$\checkmark$ provide tertiary care; contribute to preventive medicine actions;

$\checkmark$ contribute to health education;

$\checkmark \quad$ contribute to research in all areas of health[41].

\subsubsection{Presentation of the National Hospital of Lamordé}

\subsubsection{Geographic location}

The Lamordé National Hospital is located in the urban community of Niamey and more specifically in commune V, on the right bank and near the Faculty of Health Sciences in Niger. The Lamordé National Hospital occupies an area of ten (10) hectares of which only 2.5 ha are built. It has a capacity of 268 beds and has 414 agents, all categories combined from Abdou Moumouni University in Niamey. It remains the only tertiary health facility to have a functional dialysis unit since February 27, 2002[42]. 
Inventory of Counterfeit Drugs, History of Antibiotics and Presentation of the Ministry in Charge with Four of the Largest Public Health Centers in Niger Using Them in 2016-2017

\subsubsection{Historical}

It was created on January 12, 1984, under the name of University Hospital Center (CHU), by Decree No. 84 / PCMS / MES / R of 01/01/1984. In 1986, it came under the supervision of the Ministry of Public Health and becomes National Hospital of Lamordé by Ordinance $\mathrm{n}^{\circ}$ 86-011 of January 10, 1986. It is erected in EPA by Ordinance $\mathrm{n}^{\circ}$ 92-011 of April 6, 1992[42].

\subsubsection{Missions}

The mission of the National Hospital of Lamordé is to:

$\checkmark \quad$ serve as a reference center for other health facilities

$\checkmark$ provide mainly tertiary care to internal and external patients;

$\checkmark$ contribute to health education at all levels of training;

$\checkmark$ contribute to research in all areas of health;

$\checkmark$ contribute to preventive medicine actions.

$\checkmark$ public service mission.

It has its own assets and enjoys financial autonomy according to Ordinance 92-011 of 6 April 1992, Article 1.

For the accomplishment of these missions, the state contributes around $72 \%$ in the mobilization of financial resources by granting it a balance subsidy[42].

\subsubsection{Presentation of the Issaka Gazoby Maternity Hospital (MIG)}

\subsubsection{Geographic location}

Located in the city center of Niamey, MIG is limited to the east by CISLSLS, CNTAT, CNR / IST, CNRP, DRSP / CUN and HIV (CTA), to the west by MP / PF / PE, to the north by the DST, the regional section (CR) and the ANPE, to the south by the CNR and the $\mathrm{CC}[40]$.

\subsubsection{Historical}

The Central Maternity of Niamey was created in 1929 and erected as a Public Establishment of an administrative nature in 1996 by Ordinance No. 96-69 of November 28, 1996.

Its creation came back at the time as part of the hospitalization (forced at the time) of pregnant women until the 7 th day after childbirth.

Located in the administrative and business district of the capital, the Issaka Gazoby Maternity constitutes one of the essential links of the health pyramid of Niger.

The denomination of "Maternity ISSAKA GAZOBY" took place in 1997, in homage to the first Obstetrician Gynecologist, Doctor Issaka Gazoby. The latter indeed rendered eminent services to the Nigerien populations during his career in health facilities and in particular at the Central Maternity of Niamey where he occupied the post of Director General. From 1929 to 1947 , the Central Maternity was composed of mud huts with clay bedding and mats. Pregnant women were forcibly hospitalized there from the eighth month of pregnancy until the seventh day after delivery.

In 1948, FIDES rehabilitated the Maternity Hospital by providing two (02) modern buildings with midwifery accommodation and a majestic hospital pavilion. It was headed at that time by Hélène Bassy Wattara, originally from Saint Louis of Senegal, the first and only midwife.

In 1973, came a gynecologist - obstetrician of French nationality, Doctor Guy Bianchi. Thanks to the financial support of the EDF, a new pavilion with 23 beds and an equipped technical platform are built and equipped with two (02) operating theaters, three (03) rooms with eight (08) delivery tables.

The first Nigerian obstetrician-gynecologist, Doctor Issaka Gazobi arrived in 1978 and was appointed Chief Medical Officer of the institution. A third rehabilitation took place in 1993 with the support of Spain and the EDF. Maternity is now reinforced by specialized units (laboratory, imaging, neonatology, etc.)[40].

\subsubsection{Missions}

National structure of 3 rd level of reference, its main missions are to:

$\checkmark$ provide gynecological, obstetrical, neonatal and post-natal services at the tertiary level and family planning activities and prevention of mother-to-child transmission of HIV;

$\checkmark$ ensure fetal-maternal protection;

$\checkmark \quad$ serve as a training, coaching and research framework in gynecology, obstetrics and neonatology;

$\checkmark \quad$ welcome references.

It also aims to provide free treatment for gynecological and breast cancers until the National Center for Radiotherapy is operational[40].

\subsubsection{Presentation of the Poudrière Regional Hospital Center (CHR)}

\subsubsection{Geographic location}

Located in the heart of the commune II of Niamey, particularly in the powder magazine district not far from the new castle (9), the CHR is spread over an area of about ten (10) hectares[43]. 


\section{Inventory of Counterfeit Drugs, History of Antibiotics and Presentation of the Ministry in Charge with Four of the Largest Public Health Centers in Niger Using Them in 2016-2017}

\subsubsection{Historical}

Historically called powder maternity, but including within it a maternity and a maternal and child protection center (PMI) created in 1979. These entities were intended to provide health assistance by regular monitoring of pregnant women, those breastfeeding and infants. In 1993, following the restructuring of the central maternity, it was transformed into a reference center.

On Sept (7) March 2002, it was set up as a district hospital with budgetary autonomy pending its legal status by letter $\mathrm{N}^{\circ} 0163$ / MSP / LCE / DGSP.

Thus, the Poudrière Regional Hospital Center in Niamey was created by decree No. 0212 / MSP / LCE / DMH of August $27,2002$. It is the result of the regrouping of two health structures, namely the powder magazine maternity, and the former powder and maternal health center, which is why it is commonly called "powder magazine hospital".

The transformation works of the two aforementioned structures were entirely funded by French cooperation for an amount of two hundred ninety-five million thirteen thousand four hundred seventy-one CFA francs $(295,013,471)$ in the framework of project No. 96014400 entitled "Support for the Niamey II health district policy" approved on November 19, 1996.

Under the supervision of the prefect president of the CUN, the CHR of Niamey is under the authority of a director assisted by a team made up of a manager, a general supervisor and a bursar[43].

\subsubsection{Missions}

Started its activities in 2003, the powder magazine CHR has four (4) main missions:

$\checkmark$ care mission: quality care corresponding to the second level of the country's health pyramid with the role of serving as a reference for Niamey district hospitals with their network of integrated health centers and health huts;

$\checkmark$ training mission: training ground for health workers in the fields of initial training as well as retraining and continuing education;

$\checkmark$ research mission: action research in health illustrated by the dissertations and theses of pupils and students of health schools;

$\checkmark$ public health mission: through the implementation of health programs (HIV / AIDS, fight against malaria, etc.).

Currently, the powder magazine CHR offers these services to all five municipalities in the urban community of Niamey which, according to estimates at the National Institute of Statistics (INS) covers a population of 1,123,625 inhabitants for the year 2015.

On the administrative level, the personnel are governed by the general statute of the public service. The CHR does not have internal regulations which govern its internal functioning[43].

\section{CONCLUSION}

The review of literature on counterfeit drugs shows that different kind of drugs are used in the world exceptionally in Asia, Europe, Africa and particularly in Niger. So, many counterfeit drugs are used by the population because of the lowest prices and they don't need a prescription to buy them. The history of antibiotics was necessary to know in order to have a better knowledge of the molecule which was the subject of the rest of our research. The presentation of the Ministry of Public Health and main health centers involved in Niger provided substantial details on their functioning, in particular the functioning of these health centers, the consequences of the use of counterfeit medicines in general and antibiotics in particular.

\section{ACKNOWLEDGMENT}

The authors are very thankful to:

$\checkmark$ Faculty of Sciences and technology/department of chemistry, Abdou Moumouni University (UAM), Niamey, Niger,

$\checkmark \quad$ Niamey National Hospital,

$\checkmark$ Amirou Garga Hospital of Lamordé,

$\checkmark$ Poudrière regional Hospital Center,

$\checkmark \quad$ Maternity Issaka Gazobi,

$\checkmark$ Pharmacists and drugs sellers,

$\checkmark \quad$ Street vendors.

\section{REFERENCE}

1) OMS, «STRATEGIE PHARMACEUTIQUE DE L'OMS : Cadre d'action pour les médicaments essentiels et politique pharmaceutiques 2000-2003 », Genève, 2000.

2) SOUDAN-DELPHINE CATHERINE, « La gestion des déviations qualité sur un site de la production pharmaceutique », 2012.

3) « Médicaments : les contrefaits envahissent le marché notamment via internet. »

4) «Les faux médicaments durs à détecter », Le Figaro, 2013.

5) F. com WW, «Europe cracking down on counterfeits », FashionNetwork.com. 
Inventory of Counterfeit Drugs, History of Antibiotics and Presentation of the Ministry in Charge with Four of the Largest Public Health Centers in Niger Using Them in 2016-2017

https://ww.fashionnetwork.com/news/Europe-cracking-down-on-counterfeits,58365.html (consulted the 16th august, 2021).

6) «Cracking down on counterfeiting and piracy in the EU », www.euractiv.com, June 08, 2003.

https://www.euractiv.com/section/all/opinion/cracking-down-on-counterfeiting-and-piracy-in-the-eu/ (consulted the 16th august, 2021).

7) «La contrefaçon de médicaments, un marché lucratif- Le Quotidien du pharmacien », Le Quotidien du pharmacien.

8) «Les Médicaments contrefaits : un problème de santé en Afrique », 2013.

9) «ReMeD - Réseau Médicaments et Développement», Wikipédia. nov. 08, 2020. Consulted the 16 August, 2021. [En ligne]. Disponible sur : https://fr.wikipedia.org/w/index.php?title=ReMeD_-_R\%C3\%A9seau_M\%C3\%A9dicament s_et_D\%C3\%A9veloppement\&oldid=176370867

10) [ReMeD, «Etude sur la qualité des médicaments au Cameroun, Madagascar et Tchad », 2005.

11) « ReMed - Recherche Google». https://www.google.com/search?q=ReMed\&btnK=Recherche+Google\&sxsrf=ALeKk03bl1Ve_hv_kTUxyrDklxvyIQkQ og\%3A1629131992509\&source=hp\&ei=2JQaYZXFHNn8wAO355SgBA\&iflsig=AINFCbYAAAAAYRqi6EZmJqfq6Y NxQ15U-CfpcsUBqNGY\#btnK=Recherche\%20Google (consulté le 16 août, 2021).

12) MARIANNE NDOUR IDDRI, «Les partenariats public-privé mondiaux pour la santé », $n^{\circ}$ REVUE N $^{\circ} 07$, p. $38,2006$.

13) A. DESCLAUX et M. BADJI, «Etude d'évaluation du secteur pharmaceutique nationale du Cameroun en 2003 », UCAD, Cameroun, 2014.

14) OUEDRAGO SAMIRATOU, «Les Médicaments de la rue en zone défavorisée d'Ouagadougou (Burkina Faso) », Université Mohamed de Rabat, 2008.

15) SIMPORE MADI, «Evaluation de la stratégie nationale de lutte contre les médicaments de la rue au Burkina Faso », Université d'Ouagadougou, 2012.

16) ODILE, «Facteurs déterminant la consommation des Médicaments de la Rue en milieu urbain SP de Cote d'Ivoire », vol. Volume 35, p. 11, 2011.

17) CANDICE LEGRIS, « La détection des médicaments contrefaits par investigation de leur authenticité ; Etude pilote sur le marché pharmaceutique illicite de Cote d'Ivoire », Université de côte d'ivoire, 2007.

18) TIENDREBEOGO A.F, « Contribution la connaissance du marché parallèle des médicaments à Ouagadougou (Burkina Faso) », Université d'Ouagadougou, 1997.

19) EMILLIENNE POLA YISSIBI, «Intérêt d'un laboratoire régional de contrôle de qualité des produits pharmaceutiques en zone CEMAC », 2012, p. 16.

20) «NAFDAC aims to reduce fake drugs in circulation to zero - ADEYEYE », Vanguard News, may $02,2019$. https://www.vanguardngr.com/2019/05/nafdac-aims-to-reduce-fake-drugs-in-circulation-to-zero-adeyeye/ (consulted the 14th august, 2021).

21) DIALLO MOUSTAPHA, «Contribution à l'évaluation du marché illicite du médicament au Niger à partir des statistiques douanières d'importation des médicaments, réactifs de Laboratoire et consommables médicaux de 1999 à 2003 », Université Abdou Moumouni, FSS, 2005.

22) «Les Médicaments de la rue à Niamey: Modalités de vente et contrôle de qualité de quelques médicaments antiinfectieux », Université de Bamako, Bamako, 2005.

23) HADIZA MOUSSA ABDALLAH, « La Pharmacie par terre au Niger: une alternative à l'échec de la politique pharmaceutique nationale. Etude de cas de la Commune Niamey III », Université d'Ouagadougou, 2000.

24) M. HAMEL VINCENT, «La vente illicite de médicaments dans les pays en développement : analyse de l'émergence d'un itinéraire thérapeutique à part entière, situé en parallèle du recours classique aux structures officielles de santé », Université de Lyon, 2006.

25) JOCELYNE SAMBIRA, « Médicaments contrefaits : un problème en Afrique, L’Ampleur des profits et la légèreté des peines alimentent la criminalité », p. 35, 2013.

26) ORDONNANCE portant législation pharmaceutique. p. 52.

27) BASSIAHI ABDRAMANE SOURA, «Utilisation des médicaments de la rue à Ouagadougou », Ouagadougou, 2013.

28) «Le Circuit informel des médicaments à Yaoundé et à Niamey: Etude de la population de vendeurs et de la qualité des médicaments distribués », 2007.

29) SAOUDOGO HAMADO, «Etudes des risques de santé liés à l'utilisation des médicaments vendus sur le marché informel à Ouagadougou », Université d'Ouagadougou, 2003.

30) «Antibiotique, Classification », https://fr.wikipedia.org/wiki/Antibiotique, Classification, 2016.

31) ENSP, Niamey, « Bactériologie : les Antibiotiques, ENSP de Niamey. » 2004.

32) « santé », http://afssaps.santé.fr/htm. 
33) J.W. BENNET, what is an antibiotic. 2005.

34) D. Papp, « Histoire des antibiotiques. », Revue d'histoire des sciences, vol. 7, no 2, p. 124-138, 1954, doi : 10.3406/rhs.1954.3405.

35) W. Helfand, « Histoire des antibiotiques : The History of Antibiotic, a Symposium », Revue d'Histoire de la Pharmacie, vol. 70, n 252, p. 69-71, 1982, Consulté le: août 02, 2021. [En ligne]. Disponible sur : https://www.persee.fr/doc/pharm_0035-2349_1982_num_70_252_2185_t1_0069_0000_1

36) «L'histoire des antibiotiques », VIDAL. https://www.vidal.fr/medicaments/utilisation/antibiotiques/antibiotiques-c-estquoi/histoire.html (consulté le 02 août, 2021).

37) S. J. Allen et al., Classification of antibiotics (according to British National Formulary 2012). NIHR Journal Library, 2013. Consulted the 16 August, 2021. [In line]. Disponible sur : https://www.ncbi.nlm.nih.gov/books/NBK261327/

38) G. Karki, « Classification of antibiotics », Online Biology Notes, February 03rd, 2018. https://www.onlinebiologynotes.com/classification-of-antibiotics/ (consulted the 16 th august, 2021).

39) MSP, Niamey, « Service DAID/RP». 2015.

40) MIG, Niamey, « Service de DRH ». 2015.

41) HNN, « Service Surveillant ». 2015.

42) HNL, « Service Surveillant ». 2015.

43) CHR Poudrière, Niamey, « Service de l'Epidémiologie ». 2015. 